\title{
KEANEKARAGAMAN DAN POLA DISTRIBUSI GASTROPODA MANGROVE DI TELUK PANGPANG BLOK JATI PAPAK TN ALAS PURWO BANYUWANGI
}

\author{
Lina Susanti ${ }^{1)}$, Fuad Ardiyansayh ${ }^{2)}$, Hasyim As'ari ${ }^{3)}$ \\ ${ }^{1,2,3}$ FMIPA, Universitas PGRI Banyuwangi \\ email: fuad.bio87@gmail.com
}

\begin{abstract}
Abstrak
Keanekaragaman Gastropoda berperan terhadap stabilitas ekologi di trofik levelnya. Keberadaan gasropoda sangat berpengaruh terhadap organisme lain yang trofik levelnya lebih tinggi dari gastropoda. Tujuan penelitian ini dilakukan untuk mengetahui nilai keanekaragaman dan pola sebaran gastropoda di Hutan Mangrove Taman Nasional Jati Papak Blok Jati Alas Purwo. Metode yang digunakan dalam penelitian ini adalah dengan menggunakan metode purposive sampling. Pengambilan sampel dibagi menjadi tiga stasiun dengan masing-masing stasiun berjarak $250 \mathrm{~m}$. Tiap stasiun memiliki panjang $220 \mathrm{~m}$ dan lebar $96 \mathrm{~m}$ dengan plot berukuran $2 \times 2 \mathrm{~m}^{2}$. Hasil penelitian diperoleh 8 famili Gastropoda dengan 13 genus dan 19 spesies. Keanekaragaman gastropoda berkisar antara $\mathrm{H}^{\prime}=1.387-1.359$ yang menunjukkan bahwa wilayah tersebut memiliki nilai keanekaragaman sedang. Pola penyebaran gastropoda antar lokasi memiliki dua pola sebaran yaitu pola sebaran mengelompok dan acak.
\end{abstract}

Kata Kunci : Keanekaragaman, Pola Distribusi, Gastropoda, Mangrove

Abstract

The gastropods diversity have a role towards stability ecosystem in trophic level. The existence gastropods really take effect for other organism the trophic level higher than gastropods. The purpose of was to determine the value of diverity and distribution patterns of gastropods in the mangrove forest, Jati Papak Block National Park Alas Purwo. The method used in this research is by using purposive sampling method. Sampling was divided into three stations with a range of $250 \mathrm{~m}$ from each station. Each station is $220 \mathrm{~m}$ of long and $96 \mathrm{~m}$ of wide with a plot measuring $2 \times 2 \mathrm{~m}^{2}$. The result obtained 8 families of Gastropods with 13 genus and 19 species. Gastropods diversity ranges from $H=1.387-1.359$ which indicates that the area has a moderate diversity value. The distribution pattern of gastropods between location has two distribution patterns, namely clustered and random distribution patterns.

Keywords: Diversity, Distribution patterns, Gastropods, Mangrove

\section{PENDAHULUAN}

Kawasan hutan mangrove memiliki organisme yang beragam dan menjadikan mangrove sebagai daerah tempat asuhan (nursery ground), daerah 
tempat untuk mencari makan (feeding ground) dan daerah untuk pemijahan (spawning ground) (Bengen, 2000). Salah satu organisme yang paling banyak dijumpai pada ekosistem mangrove adalah kelompok Moluska (Kathiresan, 2001). Kelompok Moluska yang paling banyak adalah dari kelas Gastropoda, peran penting Gastropoda dalam kaitanya dengan komponen biotik di kawasan hutan mangrove, di samping sebagai detritus, Gastropoda berperan dalam proses dekomposisi serasah dan menetralisasi materi organik yang bersifat herbivor dan detrivor, serta berperan penting dalam rantai makanan untuk kesetabilan ekosistem, karena dapat mendukung kehidupan hewan lain yang lebih tinggi trofiknya (Irwanto, 2006).

Kawasan mangrove Blok Jati Papak adalah salah satu kawasan yang menjadi area konservasi Taman Nasional Alas Purwo yang banyak menghasilkan bahan organik yang berasal dari mangrove itu sendiri. Mangrove di Blok Jati Papak Taman Nasional Alas Purwo termasuk ke dalam golongan fringe (tepian pantai) mangrove, yaitu mangrove yang berada di tepian pantai dengan substrat pasir berlupur yang dipengaruhi oleh pasang surut dan umumnya didominasi oleh famili Rhizophora sp. Sampai saat ini keberadaan Gastropoda baik secara keanekaragaman serta aspek-aspek ekologi di ekosistem mangrove Blok Jati Papak masih belum banyak dilakukan oleh peneliti.

Terbatasnya informasi mengenai Gastropoda di Blok Jati Papak Taman Nasional Alas Purwo ini mendorong peneliti ingin melakukan studi pendahuluan untuk mengetahui bagaimana tingkat keanekaragaman dan pola distribusi Gastropoda didaerah tersebut. Berdasarkan uraian diatas maka perlu adanya penelitian pendahuluan tentang judul "Keanekaragaman Dan Pola Distribusi Gastropoda Mangrove di Teluk Pangpang Blok Jati Papak Taman Nasional Alas Purwo Banyuwangi”.

\section{METODE PENELITIAN}

Lokasi pengambilan sampel berada di kawasan Teluk Pangpang Blok Jati Papak Taman Nasional Alas Purwo. Penentuan lokasi penelitian ditentukan berdasarkan survey lapangan dan kondisi ekosistem mangrove yang berada di 
Blok Jati Papak Taman Nasional Alas Purwo. Teknik sampling dalam penelitian ini adalah purposive sampling dengan intensitas yang digunakan sebesar 3\% dari luas areal mangrove. Pengambilan sampel dibagi menjadi 3 stasiun dengan jarak tiap stasiun $250 \mathrm{~m}$. Panjang stasiun 1 sebesar $620 \mathrm{~m}$, panjang stasiun 2 sebesar $220 \mathrm{~m}$ dan panjang stasiun 3 sebesar $220 \mathrm{~m}$ sedangkan lebar sebesar $96 \mathrm{~m}$. Setiap stasiun dibagi menjadi 4 garis transek jarak tiap garis transek $20 \mathrm{~m}$, dalam satu garis transek terdapat 10 plot. Titik awal garis transek ditentukan dengan menggunakan GPS Garmin yang dibentangkan tegak lurus terhadap garis pantai mulai dari vegetasi terluar ke arah daratan sampai batas akhir vegetasi mangrove. Setiap garis transek diletakkan plot berukuran $2 \times 2 \mathrm{~m}^{2}$ dengan jarak tiap plot pada stasiun 1 sebesar $60 \mathrm{~m}$, satasiun 2 sebesar $20 \mathrm{~m}$, dan setasiun 3 sebesar $20 \mathrm{~m}$ (Aji, 2006).

\section{Analisis Data}

\section{Keanekaragaman}

Menurut Rustrianto (2015), keanekaragaman gastropoda dapat dihitung dengan menggunakan rumus keanekaragaman Shannon-Wiener sebagai berikut:

$$
H^{\prime}=-\sum\left(\frac{\mathrm{ni}}{\mathrm{N}}\right) \ln \left(\frac{\mathrm{ni}}{\mathrm{N}}\right)
$$

Keterangan : $\mathrm{H}^{\prime}$ = Indeks Keanekaragaman Shannon-Wienner.

ni $=$ jumlah individu setiap jenis $i$.

$\mathrm{N}=$ total individu semua jenis.

\section{Pola Distribusi Gastropoda}

Menurut Krebs (1989), pola penyebaran Gastropoda dalam penelitian ini dapat ditentukan dengan menggunakan indeks Morista. Indeks ini dapat dihitung dengan menggunakan rumus Morisita, yaitu :

$$
I d=n\left[\frac{\sum x i^{2}-\sum x}{\left(\sum x\right)^{2}-\sum x}\right]
$$

Keterangan : Id: Indeks penyebaran Morista

$$
\mathrm{n} \text { : jumlah unit pengambilan sampel }
$$


xi: jumlah individu tiap petak sampel

$\mathrm{x}$ : jumlah individu total yang diperoleh

Pengujian lebih lanjut apakah penyebaran tersebut acak atau tidak maka harus diuji dengan menggunakan rumus Chi-Square yaitu :

$$
x^{2}=\left(\frac{n \sum x^{2}}{N}\right)-N
$$

Keterangan: $x^{2}$ : Chi Square

$\mathrm{n} \quad$ : Jumlah stasiun pengambilan

$\mathrm{N}$ : Jumlah total individu seluruh stasiun

$\sum x^{2} \quad$ Jumlah total individu yang diperoleh

\section{Analisis Korelasi}

Pengaruh faktor abiotik dengan menggunakan analisis korelasi memakai software statistik SPSS 16.

\section{HASIL DAN PEMBAHASAN}

Dari hasil eksplorasi gastropoda yang dilakukan di Teluk Pangpang Blok Jati Papak Taman Nasional Alas Purwo ditemukan gastropoda sebanyak 8 famili, 13 genus dan 19 spesies, 8 famili diantaranya famili Potamididae, famili Muricidae, famili Neritiidae, famili Littorinidae, famili Nassaridae, famili Cerithiidae, famili Asimiedae, dan famili Ellobiidae yang dapat dilihat pada tabel 1 di bawah ini.

Tabel 1. Jenis Gastropoda yang Ditemukan dmi Lokasi Penelitian

\begin{tabular}{|c|c|c|c|}
\hline No & Famili & Genus & Spesies \\
\hline \multirow[t]{4}{*}{1} & Potamididae & Terebralia & Terebraliasulcata (Born, 1778) \\
\hline & & Cerithidea & Cerithidea cingulata (Gmelin, 1790) \\
\hline & & & C. obtusa (Lamarck, 1822) \\
\hline & & Telescopium & $\begin{array}{l}\text { Telescopium telescopium (Linnaeus, } \\
\text { 1767) }\end{array}$ \\
\hline 2 & Muricidae & Chicoreus & $\begin{array}{l}\text { Chicoreus capucinus (Lamarck, } \\
\text { 1822) }\end{array}$ \\
\hline
\end{tabular}




\begin{tabular}{|c|c|c|c|}
\hline & & & C. brunneus (Link, 1807) \\
\hline & & Thais & Thais tuberosa (Roding, 1798) \\
\hline \multirow[t]{2}{*}{3} & Neritiidae & Nerita & Nerita undata (Linnaeus, 1758) \\
\hline & & & N. articulata (Gould, 1847) \\
\hline \multirow[t]{3}{*}{4} & Littorinidae & Littoraria & Littoraria scabra (Linnaeus, 1758) \\
\hline & & & L. melanostoma (Bray, 1839) \\
\hline & & & L. caranifera (Menke, 1830$)$ \\
\hline \multirow[t]{3}{*}{5} & Nassaridae & Hebra & Hebra coticata (Adams, 1833) \\
\hline & & Nassarius & Nassarius melanioides (Reeve, 1853) \\
\hline & & & N. olivaceus (Bragulire, 1789) \\
\hline 6 & Cerithiidae & Rhinoclavis & Rhinoclavis aspera (Linnaeus, 1758) \\
\hline 7 & Asimiedae & Sphaerassiminea & $\begin{array}{l}\text { Sphaerassiminea miniata (Pfeiffer, } \\
1854 \text { ) }\end{array}$ \\
\hline \multirow[t]{2}{*}{8} & Ellobiidae & Cassidula & $\begin{array}{l}\text { Cassidula aurisfelis (Bruguiere, } \\
\text { 1789) }\end{array}$ \\
\hline & & Detracia & Detracia floridana (Pfeiffer, 1856) \\
\hline
\end{tabular}

Banyaknya genus dari Famili Potamididae yang ditemukan dikarenakan famili ini merupakan penghuni asli hutan mangrove. Menurut Kathiresan (2001) menyatakan bahwa salah satu Gastropoda yang banyak mendominasi di ekosistem mangrove adalah dari famili Potamididae dan Asimiedae yang terdiri dari Genus Sphaerassiminea dan terdapat 1 spesies yaitu Sphaerassiminea Miniata. Famili Potamididae dan Asimiedae merupakan penghuni asli hutan mangrove dan hidup di daerah yang terkena pasang surut serta menyukai areal berlumpur. Gastropoda famili Potamididae mempunyai adaptasi khusus untuk dapat bertahan di kawasan mangrove. Chicoreus capucinus juga merupakan salah satu Gastropoda penghuni asli hutan mangrove, alasan mengapa Chicoreus capucinus dimasukkan kedalam Gastropoda asli mangrove karena frekuensi kehadiran Chicoreus capucinusyang hampir tidak pernah ditemukan hidup diluar ekosistem mangrove (Hawkes, 1987).

Famili Littorinidae ditemukan satu genus yaitu Littoraria dan terdapat 3 spesies antara lain Littorina scabra, L. melanostoma, dan L. caranifera.Famili Littorinidae merupakan Gastropoda fakultatif, alasan mengapa famili tersebut merupakan fakultatif karena ditemukan dalam jumlah besar baik didalam maupun diluar ekosistem mangrove. Famili Littorinidae mempunyai ciri khas, yaitu individu yang menempel diakar dan atau bagian bawah mangrove akan 
mempunyai warna cangkang yang lebih gelap, sedangkan individu yang ditemukan di bagian atas sampai daun mempunyai warna cangkang yang lebihcerah dan bersih. Hal tersebut dilakukan untuk menghindari pemangsa (Reid, 1986).

Kelompok Gastropoda pengunjung yang ditemukan pada penelitian ini yaitu Chicoreus brunneus, Thais tuberosa, Nerita undata, N. articulate, Hebra corticata, Nassarius melanoides, dan N. olivaceus, Rhiniclavis aspera, Cassidula aurisfelis, Detracia floridana. Disebut Gastropoda pengunjung karena frekuensi kehadiran dan jumlah individu didalam ekosistem mangrove sangat rendah, sedangkan diluar ekosistem mangrove jauh lebih tinggi. Jenis tersebut hadir didalam ekosistem mangrove karena ketidak sengajaan terbawa arus (Cappenbreg, 2006).

Tabel 2. Indeks Keanekaragaman Tiap Stasiun Gastropoda di Teluk Pangpang TNAP

\begin{tabular}{lcl}
\hline Stasiun & $\mathbf{H}^{\prime}$ & Makna \\
\hline Stasiun 1 & 1,387 & Sedang \\
\hline Stasiun 2 & 1,383 & Sedang \\
\hline Stasiun 3 & 1,359 & Sedang \\
\hline
\end{tabular}

Keterangan : $\mathrm{H}^{\prime} \leq 1=$ keanekaragaman rendah, $\mathrm{H}^{\prime}>3=$ keanekaragaman sedang, $1 \leq \mathrm{H}^{\prime} \leq 3=$ keanekaragaman tinggi.

Indeks keanekaragaman $\left(\mathrm{H}^{\prime}\right)$ tertinggi terdapat pada stasiun I dengan nilai $\mathrm{H}^{\prime}$ adalah 1,387. Tingginya keanekaragaman pada stasiun 1 ini disebabkan karena mangrove pada stasiun 1 lebih tebal dibandingkan stasiun 2 dan stasiun 3 . Hal tersebut di perkuat oleh Pamutri (2013) yang menyatakan bahwa tebalnya vegetasi mangrove mengindikasikan keanekaragaman jenis Gastropoda. Selain itu parameter faktor abiotik yang mendukung seperti suhu, $\mathrm{pH}$ dan salinitas di stasiun 1 tergolong baik untuk kelangsungan hidup Gastropoda.

Keanekaragaman terendah terdapat pada stasiun 3 dengan indeks keanekaragaman 1,359, berdasarkan pengamatan yang menyebabkan stasiun 3 memiliki keanekaragaman terendah karena adanya aktifitas manusia yang dapat mempengaruhi keanekaragaman pada stasiun tersebut. Keanekaragaman rendah 
diakibatkan oleh jumlah variasi jenis yang ditemukan sedikit, dan ada beberapa jenis yang ditemukan dalam jumlah yang besar, sehingga menyebabkan nilai keanekaragaman pada stasiun 3 kecil. Menurut Adi (2013), bahwa suatu komunitas dikatakan memiliki keanekaragaman yang tinggi jika komunitas itu disusun oleh banyak jenis dengan kelimpahan jenis yang sama atau hampir sama, keanekaragaman dikatakan rendah jika suatu komunitas tersusun atas sedikit jenis dan hanya sedikit jenis yang dominan. Indeks keanekaragaman $\left(\mathrm{H}^{\prime}\right)$ merupakan suatu angka yang tidak memiliki satuan dengan kisaran $0-3$. Tingkat keanekaragaman akan tinggi jika nilai $\mathrm{H}^{\prime}$ lebih dari 3 , sehingga hal ini menunjukkan kondisi perairan tergolong sangatbaik. Sebaliknya jika nilai $\mathrm{H}^{\prime}$ lebih kecil sama dengan 1 maka keanekaragamannya rendah dan kondisi perairan kurang baik bagi kehidupan Gastropoda. Keanekaragaman dapat dikatakan sedang jika nilai $\mathrm{H}^{\prime}$ lebih besar sama dengan 1 tetapi $\mathrm{H}^{\prime}$ lebih kecil sama dengan 3 (Odum, 1993). Keanekaragaman pada stasiun 1, stasiun 2, dan stasiun 3 teggolong sedang, dapat dilihat dari hasil nilai keanekaragaman berkisar dari 1,359 - 1,387. Hal tersebut menunjukkan bahwa pada perairan Blok Jati Papak produtifitasnya tinggi, kondisi Ekosistemnya seimbang dan tekanan ekologinya sedang.

Tabel 3. Pola Distribusi Gastropoda Stasiun 1 di teluk Pangpang TNAP

\begin{tabular}{|c|c|c|c|c|c|c|}
\hline \multirow[b]{2}{*}{ No } & \multirow[b]{2}{*}{ Spesies } & \multicolumn{5}{|c|}{ Stasiun 1} \\
\hline & & $\begin{array}{l}\text { Rata- } \\
\text { Rata }\end{array}$ & $x^{2}$ hitung & $x^{2}$ tabel & $\alpha$ & Pola \\
\hline 1 & Terebralia sulcata & 1,625 & 0,3 & 7,814 & 0,959 & Acak \\
\hline 2 & $\begin{array}{l}\text { Cerithidea } \\
\text { cingulata }\end{array}$ & 9,4 & 2,721 & 7,814 & 0,562 & Acak \\
\hline 3 & Cerithidea obtusa & 1,25 & 0,552 & 7,814 & 0,908 & Acak \\
\hline 4 & $\begin{array}{l}\text { Telescopium } \\
\text { telescopium }\end{array}$ & 1,05 & 0,277 & 7,814 & 0,964 & Acak \\
\hline 5 & $\begin{array}{l}\text { Chicoreus } \\
\text { capucinus }\end{array}$ & 1,35 & 1,104 & 7,814 & 0,780 & Acak \\
\hline 6 & Thais tuberosa & 0,025 & 0,3 & 7,814 & 0,959 & Acak \\
\hline 7 & Chicoreus brunneus & 0,025 & 0,3 & 7,814 & 0,959 & Acak \\
\hline 8 & Nerita undata & 9,725 & 0,155 & 7,814 & 0,984 & Acak \\
\hline 9 & Nerita articulata & 3,275 & 1,083 & 7,814 & 0,785 & Acak \\
\hline 10 & Littoraria scabra & 2,275 & 0,347 & 7,814 & 0,951 & Acak \\
\hline
\end{tabular}




\begin{tabular}{|c|c|c|c|c|c|c|}
\hline \multirow[b]{2}{*}{11} & \multirow{2}{*}{$\begin{array}{l}\text { Littoraria } \\
\text { melanostoma }\end{array}$} & \multicolumn{5}{|c|}{7,814} \\
\hline & & 0,25 & 0,2 & & 0,977 & Acak \\
\hline & Littoraria & & & 7,814 & & \\
\hline 12 & caranifera & 0,4 & 0,5 & & 0,919 & Acak \\
\hline 13 & Hebra coticata & 0,025 & 0,3 & 7,814 & 0,959 & Acak \\
\hline & Nassarius & & & 7,814 & & \\
\hline 14 & melanioides & 0,225 & 0,211 & & 0,975 & Acak \\
\hline 15 & Nassarius olivaceus & 0,325 & 0,085 & 7,814 & 0,994 & Acak \\
\hline & Sphaerassiminea & & & 7,814 & & \\
\hline 16 & miniata & 18,55 & 1,530 & & 0,680 & Acak \\
\hline 17 & Cassidula aurisfelis & 1,325 & 0,791 & 7,814 & 0,854 & Acak \\
\hline 18 & Detracia floridana & 0,25 & 1,16 & 7,814 & 0,767 & Acak \\
\hline
\end{tabular}

Keterangan : Jika $x^{2}$ hitung lebih kecil dari $x^{2}$ tabel maka penyebaran gastropoda acak dan jika $x^{2}$ hitung lebih besar dari $x^{2}$ tabel maka penyebarannya mengelompok.

Tabel 4. Pola Distribusi Gastropoda Stasiun 2 di teluk Pangpang TNAP

\begin{tabular}{|c|c|c|c|c|c|c|}
\hline \multirow[b]{2}{*}{ No } & \multirow[b]{2}{*}{ Spsies } & \multicolumn{5}{|c|}{ Stasiun 2} \\
\hline & & $\begin{array}{l}\text { Rata- } \\
\text { Rata }\end{array}$ & $x^{2}$ hitung & $x^{2}$ tabel & $\alpha$ & Pola \\
\hline 1 & Terebralia sulcata & 1,75 & 0,257 & 7,814 & 0,967 & Acak \\
\hline 2 & Cerithidea cingulata & 13,5 & 1,992 & 7,814 & 0,578 & Acak \\
\hline 3 & Cerithidea obtusa & 1,325 & 1,213 & 7,814 & 0,754 & Acak \\
\hline 4 & $\begin{array}{l}\text { Telescopium } \\
\text { telescopium }\end{array}$ & 1,525 & 0,136 & 7,814 & 0,987 & Acak \\
\hline 5 & Chicoreus capucinus & 2,3 & 0,504 & 7,814 & 0,918 & Acak \\
\hline 6 & Nerita undata & 9,55 & 3,436 & 7,814 & 0,330 & Acak \\
\hline 7 & Nerita articulata & 3,475 & 1,113 & 7,814 & 0,777 & Acak \\
\hline 8 & Littoraria scabra & 2,3 & 0,704 & 7,814 & 0,873 & Acak \\
\hline 9 & $\begin{array}{l}\text { Littoraria } \\
\text { melanostoma }\end{array}$ & 0,225 & 0,3 & 7,814 & 0,959 & Acak \\
\hline 10 & Littoraria caranifera & 0,5 & 0,84 & 7,814 & 0,842 & Acak \\
\hline 11 & Hebra coticata & 0,175 & 1,414 & 7,814 & 0,706 & Acak \\
\hline 12 & $\begin{array}{l}\text { Nassarius } \\
\text { melanioides }\end{array}$ & 0,225 & 0,122 & 7,814 & 0,988 & Acak \\
\hline 13 & Nassarius olivaceus & 0,125 & 0,38 & 7,814 & 0,943 & Acak \\
\hline 14 & Rhinoclavis aspera & 0,075 & 0,1 & 7,814 & 0,991 & Acak \\
\hline 15 & $\begin{array}{l}\text { Sphaerassiminea } \\
\text { miniata }\end{array}$ & 11,75 & 5,502 & 7,814 & 0,137 & Acak \\
\hline 16 & Cassidula aurisfelis & 1,075 & 1,234 & 7,814 & 0,748 & Acak \\
\hline 17 & Detracia floridana & 0,375 & 0,18 & 7,814 & 0,980 & Acak \\
\hline
\end{tabular}

Keterangan : Jika $x^{2}$ hitung lebih kecil dari $x^{2}$ tabel maka penyebaran gastropoda acak dan jika $x^{2}$ hitung lebih besar dari $x^{2}$ tabel maka penyebarannya mengelompok. 
Tabel 5. Pola Distribusi Gastropoda Stasiun 1 di teluk Pangpang TNAP

\begin{tabular}{|c|c|c|c|c|c|c|}
\hline \multirow[b]{2}{*}{ No } & \multirow[b]{2}{*}{ SpeSIes } & \multicolumn{5}{|c|}{ Stasiun 3} \\
\hline & & $\begin{array}{l}\text { Rata- } \\
\text { Rata }\end{array}$ & $x^{2}$ hitung & $x^{2}$ tabel & $\alpha$ & Pola \\
\hline 1 & Terebralia sulcata & 1,45 & 2,931 & 7,814 & 0,596 & Acak \\
\hline 2 & $\begin{array}{l}\text { Cerithidea } \\
\text { cingulata }\end{array}$ & 3,125 & 15,74 & 7,814 & 0,001 & Mengelompok \\
\hline 3 & Cerithidea obtusa & 0,9 & 5,822 & 7,814 & 0,117 & Acak \\
\hline 4 & $\begin{array}{l}\text { Chicoreus } \\
\text { capucinus }\end{array}$ & 1,875 & 4,975 & 7,814 & 0,172 & Acak \\
\hline 5 & Thais tuberosa & 0,025 & 0,3 & 7,814 & 0,959 & Acak \\
\hline 6 & $\begin{array}{l}\text { Chicoreus } \\
\text { brunneus }\end{array}$ & 0,025 & 0,3 & 7,814 & 0,959 & Acak \\
\hline 7 & Nerita undata & 11,425 & 19,402 & 7,814 & 0,001 & Mengelompok \\
\hline 8 & Nerita articulata & 3,825 & 8,378 & 7,814 & 0,038 & Mengelompok \\
\hline 9 & Littoraria scabra & 2,425 & 4,762 & 7,814 & 0,188 & Acak \\
\hline 10 & $\begin{array}{l}\text { Littoraria } \\
\text { melanostoma }\end{array}$ & 0,175 & 0,271 & 7,814 & 0,964 & Acak \\
\hline 11 & $\begin{array}{l}\text { Littoraria } \\
\text { caranifera }\end{array}$ & 0,075 & 0,9 & 7,814 & 0,827 & Acak \\
\hline 12 & Hebra coticata & 0,025 & 0,3 & 7,814 & 0,959 & Acak \\
\hline 13 & $\begin{array}{l}\text { Nassarius } \\
\text { melanioides }\end{array}$ & 0,25 & 0,04 & 7,814 & 0,998 & Acak \\
\hline 14 & $\begin{array}{l}\text { Sphaerassiminea } \\
\text { miniata }\end{array}$ & 1,075 & 12,9 & 7,814 & 0,005 & Mengelompok \\
\hline 15 & $\begin{array}{l}\text { Cassidula } \\
\text { aurisfelis }\end{array}$ & 0,025 & 0,3 & 7,814 & 0,959 & Acak \\
\hline 16 & Detracia floridana & 0,025 & 0,3 & 7,814 & 0,959 & Acak \\
\hline
\end{tabular}

Keterangan : Jika $x^{2}$ hitung lebih kecil dari $x^{2}$ tabel maka penyebaran gastropoda acak dan jika $x^{2}$ hitung lebih besar dari $x^{2}$ tabel maka penyebarannya mengelompok.

Pola persebaran dari ketiga stasiun diatas dapat dilihat bahwa pada stasiun 1 dan 2 terdapat 1 pola penyebaran yaitu pola penyebaran yang bersifat acak. Pola penyebaran acak karena memiliki nilai $x^{2}$ hitung antara 0,084 - 2,721 lebih kecil dari $x^{2}$ tabel yaitu 7,814, hal ini menunjukkan bahwa kelompok tersebut tidak memiliki kecenderungan untuk hidup berkoloni dan dapat bertahan hidup di beberapa tempat lokasi penelitian. Sedangkan pada pola persebaran pada stasiun 3 terdapat 2 pola yaitu bersifat acak dan mengelompok. Pola persebaran acak menandakan bahwa kelompok Gastropoda tersebut keberadaan jenisnya tidak 
memiliki kecenderungan untuk hidup berkoloni dan dapat bertahan hidup di beberapa lokasi tempat penelitian. Jenis Gastropoda yang bersifat acak mampu beradaptasi di hampir semua kondisi lingkungan. Pola penyebaran Gastropoda yang bersifat acak juga menandakan adanya persaingan yang positif antar individu sehingga terbentuknya pembagian ruang antar individu (Kamalia, 2011).

Pola penyebaran Gastropoda yang bersifat mengelompok karena jenis-jenis hewan yang ditemukan dalam jumlah yang banyak dalam setiap jenis dan mendominasi suatu area persebaran secara mengelompok ini memiliki kecenderungan dengan jenis yang lain dalam memperoleh makanan, serta memiliki sifat mobile yang rendah sehingga sulit berpindah tempat dan menyebar. Pola hidup mengelompok berkaitan erat dengan kondisi lingkungan, kebiasaan mereka makan dan reproduksi. Pola penyebaran Gastropoda yang bersifat mengelompok karena jenis-jenis hewan yang ditemukan dalam jumlah yang banyak dalam setiap jenis dan mendominasi suatu area. Pola hidup mengelompok berkaitan dengan beberapa faktor yaitu habitat yang paling sesuai didasar perairan, baik sesuai dengan faktor fisika kimia perairan, maupun tersedianya makanan sehingga Gastropoda dapat mempertahankan diri dan berkembang biak dengan baik. Persebaran secara mengelompok ini memiliki kecenderungan dengan jenis yang lain dalam memperoleh makanan, serta memiliki sifat mobile yang rendah sehingga sulit berpindah tempat dan menyebar (Sitorus, 2008).

Tabel 6. Korelasi Keanekaragaman Dan Faktor Abiotik

\begin{tabular}{lccccc}
\hline \multicolumn{6}{c}{ Korelasi } \\
& Keanekaragaman & Suhu & pH_air & Salinitas & Pasang \\
\hline Keanekaragaman & 1 & $\begin{array}{c}- \\
1.000^{* *}\end{array}$ & -.945 & $-1.000^{* *}$ & -.859 \\
\hline
\end{tabular}

Keterangan : $0=$ Tidak ada hubungan, $-1=$ linier sempurna negatif, $1=$ linier sempurna positif, $* * .=$ signifikasi 0.01 
Hubungan keanekaragaman dengan suhu dan salinitas sebesar $-1,000 * *$ artinya besar korelasi antara variabel keanekaragaman dengan suhu dan salinitas mempunyai nilai linier sempurna negatif, dapat disimpulkan bahwa terdapat hubungan yang signifikan antara kedua variabel, tanda bintang menunjukkan signifikasi bernilai 0,01 dan mempunyai kemungkinan dua arah, jika keanekaragaman naik maka suhu dan salinitas akan turun. Menurut Pamutri (2013), menyatakan bahwa jika suhu dalam kondisi tinggi maka menyebabkan penguapan tinggi, hal itu mengakibatkan substrat menjadi kering sehingga terjadi penurunan keanekaragaman Gastropoda, karena banyak dari gastropoda yang tidak mampu mentoleransi terhadap suhu yang tinggi. Cahaya matahari yang diserap oleh badan air akan menghasilkan panas di perairan, sehingga cahaya matahari akan meningkatkan salinitas perairan (Odum, 1993). Tinggi dan waktu penggenangan air laut juga akan sangat menentukan salinitas tanah yang dapat dimanfaatkan oleh biota laut. Perairan pantai salinitas bisa turun rendah karena terjadi pengenceran oleh air tawar,misalnya oleh air sungai yang mengalir ke laut serta ketika hujan (Nontji, 1986).

Hubungan keanekaragaman dengan $\mathrm{pH}$ dengan nilai korelasi -0,945 yang artinya bahwa besar korelasi antara variabel keanekaragaman dengan $\mathrm{pH}$ mempunyai nilai linier negatif. Nilai korelasi keanekaragaman dan $\mathrm{pH}$ mendekati -1.00 dapat disimpulkan bahwa terdapat hubungan yang signifikan antara kedua variabel dengan nilai signifikasi 0,05 dan mempunyai kemungkinan dua arah, jika keanekaragaman naik maka $\mathrm{pH}$ akan turun. Sebagian besar biota akuatik khususnya Gastropoda sensitif terhadap perubahan $\mathrm{pH}$. Menurut Dewiyanti (2004) menyatakan bahwa pH yang tinggi dapat mendukung organisme pengurai untuk menguraikan bahan-bahan organik yang jatuh didaerah mangrove, sehingga tanah mangrove yang berderajat keasaman tinggi mempunyai karbon organik yang hampir sama dengan profil tanah yang dimilikinya.Air laut mempunyai kemampuan penyangga yang sangat besar untuk mencegah perubahan $\mathrm{pH}$. Perubahan $\mathrm{pH}$ sedikit saja dapat mengganggu sistem penyangga, hal ini dapat menimbulkan perubahan dan ketidak seimbangan kadar $\mathrm{CO}_{2}$ yang dapat membahayakan kehidupan biota laut. umumnya perairan laut maupun 
pesisir memiliki $\mathrm{pH}$ relatif lebih stabil dan berada dalam kisaran yang sempit, biasanya berkisar antara 7,6 - 8,3 yang berarti bersifat basa atau disebut alkali. Kondisi tertentunilainya dapat berubah menjadi lebih rendah sehingga menjadi bersifat asam. Perubahannilai $\mathrm{pH}$ yang demikian dapat berpengaruh terhadap kualitas perairan yang pada akhirnyaakan berdampak terhadap kehidupan biota didalamnya (Effendi, 2003).

Nilai korelasi antar keanekaragaman dengan pasang dengan nilai -0,859, artinya hubungan antara keanekaragaman dengan pasang tidak searah. Pada saat pasang naik organisme yang berada didaerah tertentu dapat berpindah organisme tersebut dapat didistribusikan kedaerah yang lain, pada waktu pasang surut organisme yang terbawa akan berhenti dan dijadikan sebagai tempat distribusinya, hal tersebut yang mempengaruhi keanekaragaman pada suatu daerah. Beberapa Gastropoda memiliki kemampuan dalam menghindari pasang surut dengan cara bergerak aktif turun naik seirama dengan pasang surut. Selama air pasang Gastropoda akan bergerak keatas sampai ketinggian sedikit diatas air dan pada saat surut, sebagian besar Gastropoda turun ke batang pohon bagian bawah atau merayap di substrat. Semakin tinggi dan lama waktu pasang naik maka akan mempengaruhi aktifitas Gastropoda (Budiman, 2009).

\section{KESIMPULAN DAN SARAN}

\subsection{Kesimpulan}

Diapatkan 8 famili, 13 genus dan 19 spesies, 8 famili diantaranya famili Potamididae, famili Muricidae, famili Neritiidae, famili Littorinidae, famili Nassaridae, famili Cerithiidae, famili Asimiedae, dan famili Ellobiidae dengan Indeks keanekaragaman $\mathrm{H}^{\prime}=1,359-1,387$ katagori sedang dengan pola distribusi acak dan mengelompok.

\subsection{Saran}

Untuk mendapatkan hasil spesimen yang lebih beragam disarankan untuk pengambilan spesiemen dilakukan pada saat surut, sehingga memudahkan pada saat ekplorasi hutan mangrove. 


\section{REFERENSI}

Adi J, S. 2013. Komposisi Jenis dan Pola Penyebaran Gastropoda Hutan Mangrove Blok Bedul Segoro Anak Taman Nasional Alas Purwo Banyuwangi. Program Biologi, PMIPA FKIP, Universitas Jember.

Aji. E,H. 2006. Keanekaragaman Jenis Gastropoda Di Pantai Randusanga Kabupaten Brebes Jawa Tengah. Skripsi. Universitas Negri Semarang.

Ayunda, Ranti. 2011. Struktur Komunita Gastropoda Pada ekosistem Mangrove Di Gugus Pulau Pari Kepulauan Seribu. UI. Jakarta.

Bengen, D.G. 2004. Pedoman Teknis Pengelolaan Ekosistem Mangrove. Pusat Kajian Pesisir dan Lautan. IPB. Bogor.

Bolam, S. G., T. F. Fernandez dan M. Huxham. 2002. Diversity, Biomass, and ecosystem proses in the marine benthos. Ecological Monograph.

Budiman, A. 2009. Persebaran dan Pola Kepadatan Moluska di Hutan Bakau. Jurnal Biologo.

Dewiyanti, I. 2004. Struktur Komunitas Molusca (Gastropoda dan Molusca) Serta Asosiasinya Pada Ekosistem Mangrove di kawasan pantai Ulee-Lheue Banda Aceh NAD. Bogor: Institut Pertanian Bogor.

Dharma, B . 1988. Indonesian Shells. Jakarta : Sarana Graha

Effendi, H. 2003. Telaah Kualitas Air bagi Pengelolaan Sumber Daya dan Lingkungan Perairan. Cetakan Kelima. Yogjakarta : Kanisius.

Frith, D. W. 1977. A Premilinary List Of Macrofauna From A Mangrove. Marine Pollution Bulletin. New York.

Hartanto, L. 2011. Pola Pengelompokan Vegetasi Mangrove di Teluk Pangpang Taman Nasional Alas Purwo. Tesis Pascasarjana Universitas Gajah Mada: Yogyakarta.

Hartoni. \& A. Agussalim. 2012. Komposisi dan Kelimpahan Moluska (Gastropoda dan Bivalvia) di Ekosistem Mangrove Muara Sungai Musi Kabupaten Banyuasin Provinsi Sumatera Selatan. Jurnal.

Hawkes, H, A. 1978. Invertebrates as Indicator of Rifver Water Quality. LIPI Bogor. Hegner, R.B. \& J.G. Engemann. 1968. Invertebrata Zoology. New York : Macmillan Publishing Co. INC

Irwanto. 2006. Keanekaragaman Fauna Pada Habitat Mangrove. Yogyakarta.

Kamalia, Mustika. 2004. Pola Sebaran Gastropoda Di Ekosistem Mangrove Kelurahan Tanjung Ayun Sakti Kecamatan Bukit Bestari Kota Tanjung pinang. Tanjung Pinang. FIKP UMRAH.

Kathiresan, K. and B.L. Bingham. 2001. Biology of Mangroves and Mangrove Ecosystems. Centre of Advanced Study in Marine Biology. Annamalai University, India.

Krebs, C.J. 1989. Ecological Methodology. Harper Collins Publisher, Inc. New York. Kusrini, D. M. 2000. Komposisi dan Struktur Komunitas Keong Pottamididae di Hutan Mangrove Teluk Harun Kecamatan Padang Cermin, Naputen Lampung Selatan. Skripsi. Departemen Sumberdaya Perairan. Institut 
Pertanian Bogor. Bogor

Mujiono, N. 2008. Mudwhelks Gastropoda from mangrove of ujung kulon national park. Banten.

Nurjanah. Muzahar, Henky Irawan. 2003. Keanekaragaman Gastropoda Di Padang Lamun Perairan Kelurahan Senggarang Kota Tanjungpinang Provinsi Kepulauan Riau. Universitas Maritim Raja Ali Haji. Tanjungpinang.

Nontji, A. 2002. Laut Nusantara. Djambatan Jakarta.

Odum , E. P. 1993 .Dasar - dasar Ekologi. Terjemahan Tjahjono Samingan. Yogyakarta : Gadjah Mada University Press

Pamutri, D. T. 2013. Hubungan Kerapatan Jenis Vegetasi Mangrove Dengan Keanekaragaman Jenis Gastropoda di Hutan Mangrove Blok Bedul Segoro Anak Taman Nasional Alas Purwo. PMIPA FKIP, Universitas Jember.

Pemerintah Kabupaten Banyuwangi, 2014. Forum Pengelolaan Ekosistem Esensial Lahan Basah/Kawasan Mangrove Teluk Pangpang Kabupaten Banyuwangi. Wetlands International dan Balai Besar KSDA Jawa Timur.

Phechenik, J.A. 1998. Biology of the Invertebrates. Companies. New York.

Raharja, A.P., Widigdo, B., dan Sutrisno, D. 2014. Kajian Potensi Kawasan Mangrove di Kawasan Pesisir Teluk Pangpang Banyuwangi. Bogor.

Rahmawati, Gita. 2013. Ekologi Keong Bakau (Telescopium telescopium) Pada Ekosistem Mangrove Pantai Mayangan Jawa Barat. Skripsi Institut Pertanian Bogor. Bogor.

Reid, D., G. 1986. The Littorinid molluscs of mangrove forests in the Indo-Pasific Region. London.

Rustrianto, Yanuar, B. 2015. Potensi Fauna Akuatik Ekosistem Hutan Mangrove Di Kawasan Teluk Pangpang Kabupaten Banyuwangi. Universitas Udayana. Denpasar.

Sanmugam, A. \& S. Vairamani. 2008. Mollusca in Mangrov: A case study. Centre of advance trudy in marine biology. New York.

Sitorus, Dermawan BR. 2008. Keanekaragaman dan Distribusi Bivelvia Serta Kaitannya dengan Faktor Fisika-Kimia di Perairan Pantai Labu Kabupaten Deli Serdang.Tesis Universitas Sumatra Utara.

Sulawesty, F. \& M. Badjori. 1999. Struktur komunitas makrozoobentos di perairan Situ Cibuntu. PUSLITBANG. Biologi LIPI, Bogor.

Susanti, Mulyani. S., Bhudiati. R. 2008. Analisis Keanekaragaman Gastropoda Pada Komunitas Mangrove di Perairan Muara Reja Kota Tegal. Cermin.

Susetiono. 2005. Krustacea dan Mollusca Mangrove Delta Mahakam. Pusat Penelitian Oseanografi - LIPI. Jakarta.

Suwondo, Febrita E., Sumanti F. 2005. Struktur Komunitas Gastropoda Pada Hutan Mangrove Di Pulau Sipora Kabupaten Kepulauan Mentawai Sumatera Barat. Sumatra.

Syahrodin, Lutfi P. 2015. Keanekaragaman kerang (Bivalvia) di Zona Intertidal Teluk Pangpang Kecamatan Muncar Kabupaten Banyuwangi dan Pemanfaatannya Sebagai Buku Suplemen, Skripsi Universitas Negri Jember. 